\title{
Effect of Ochratoxin A and Aristolochic Acid on an Epithelial Intestinal Cell Line
}

\author{
Daniela MARIN*, Monica MOTIU, Ionelia TARANU \\ Laboratory of Animal Biology, INCDBNA Balotesti, Romania \\ *Corresponding author, email:_daniela.marin@ibna.ro
}

Bulletin UASVM Animal Science and Biotechnologies 71(2) / 2014,

Print ISSN 1843-5262; Electronic ISSN 1843-536X

DOI:10.15835/buasvmcn-asb:10575

\begin{abstract}
OchratoxinA (OTA) and aristolochid acid (AA) effects on cell viability and cytokine synthesis was analysed in an intestinal epithelial porcine cell line. The highest doses of AA and OTA $(>1 \mu \mathrm{g} / \mathrm{mL})$ induce a significant $(\mathrm{P}<0.05)$ decrease of the cell viability. OTA and AA has little or no effect on IL-8 synthesis were induced a decrease of the synthesis of TNF alpha and IL-1 beta.
\end{abstract}

Keywords: aristolochic acid, epithelial intestinal cells, ochratoxin A, swine

Introduction. OchratoxinA (OTA) and aristolochic acid (AA) were associated with the Balkan endemic nephropathy (BEN), a chronic nephropathy described in several areas from the Balkan Peninsula and Romania. Even the effect at the renal level was well documented the effect of these toxins at intestinal level was no investigated.

Aims and objectives. We have investigated the effect of OTA and AA on a pig epithelial cell line: IPEC-1, in term of cell viability, and synthesis of some inflammatory cytokines: TNF alpha, IL-1 beta and IL-8.

Materials and methods. For the viability assays, IPEC-1 cells were cultivated in 96 wells plates and treated or not with $1-500 \mu \mathrm{g} / \mathrm{mL}$ OTA and AA. The cytokine synthesis was assessed in the supernatant of the cell culture by ELISA using commercial kits.

Results and discussion. With the exception of the low dose of $1 \mu \mathrm{g} / \mathrm{mL}$ dose, that induce only a slight decrease of cell viability, the higher doses of AA and OTA induce a significant $(\mathrm{P}<0.05)$ decrease of the cell viability. For example the highest dose $(500 \mu \mathrm{g} / \mathrm{mL})$ induced a decrease of cell viability with $89 \%$ and $97 \%$, for AA and respectively OTA. AA induced a progressive decrease of cell viability; by contrast OTA induced a failure of cell viability starting with the low doses $(5 \mu \mathrm{g} / \mathrm{mL})$. Cytokine synthesis, as investigated in the cell supernatant after $3 \mathrm{~h}, 6 \mathrm{~h}$ and $24 \mathrm{~h}$ of exposure revealed that OTA and AA have different effects on the secretion of cytokines involved in inflammation. Thus, OTA and AA has little or no effect on IL-8 synthesis, while TNF alpha significantly decrease after $3 \mathrm{~h}(\mathrm{P}<0.05)$ exposure to 1 and $5 \mu \mathrm{g} / \mathrm{mL}$ OTA and $5 \mu \mathrm{g} / \mathrm{mL} \mathrm{AA}$; at $24 \mathrm{~h}$ of exposure to the both toxins, the TNFalpha synthesis was reduced as compared with $3 \mathrm{~h}$. At $24 \mathrm{~h}, 5 \mu \mathrm{g} / \mathrm{mL}$ OTA induce a suppression of the cytokine synthesis. Similarly, in human peripheral blood mononuclear cells, concentrations of OTA between 5 and $7.5 \mu \mathrm{g} / \mathrm{mL}$ induced a complete

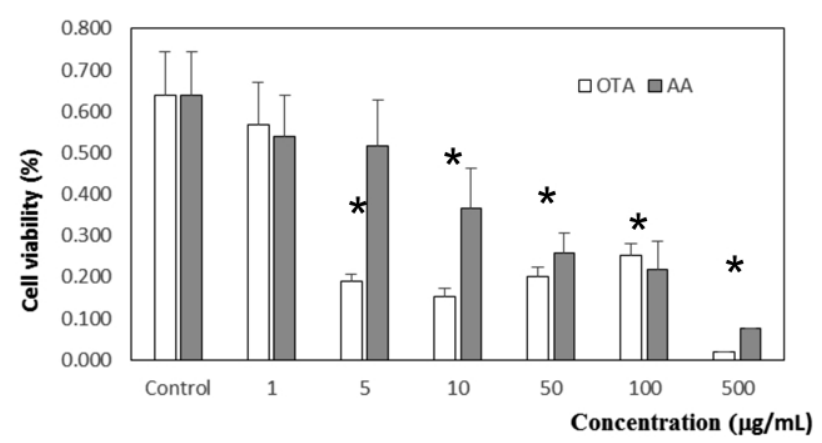

Fig. 1. Cell viability. IPEC cells were exposed to various concentrations of toxins and the viability of the cells was assessed by a MTT test. * indicate significant differences $(\mathrm{P}<0.05)$ 

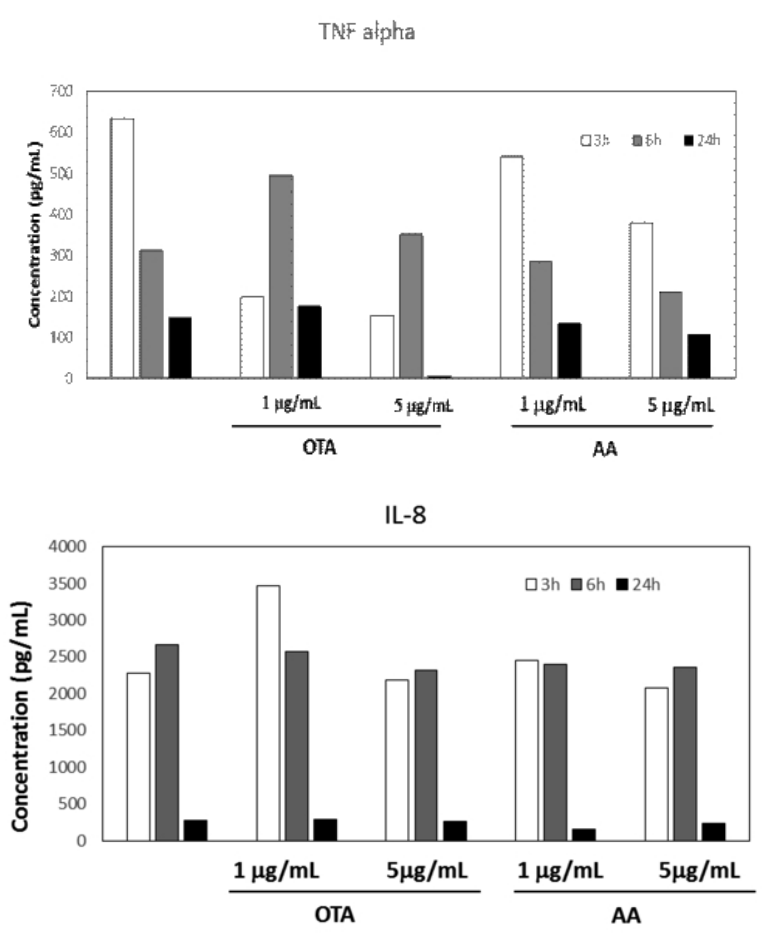

Fig. 2. Cytokine synthesis. IPEC cells were exposed to different toxins concentrations and the cytokine synthesis was determined by ELISA (a) TNF alpha synthesis (b) IL-8 synthesis

inhibition in TNF-alpha production after $24 \mathrm{~h}$ of exposure (Mechoud et al., 2012). At 6h, OTA induced an increase of the TNF-alpha synthesis for both concentrations. Rat liver sinusoidal endothelial cells, were also able to synthesize TNF-alpha in the presence of OTA, but only after LPS exposure (Al-Anati et al., 2010).
As compared with the control, AA induced provoked a slight decrease of TNF alpha synthesis. Wu et al. (2011) shown that AA, inhibits in human monocyte the TNF- $\alpha$-induced MMP-9 cells, possibly through the NF- $\mathrm{BB}$ signal pathway. A significant decrease of IL-1 beta was observed after $3 \mathrm{~h}, 6 \mathrm{~h}$ or $24 \mathrm{~h}(\mathrm{P}<0.05)$ exposure to AA and OTA; the IL-1 beta was not detected in the cell supernatant after $24 \mathrm{~h}$ of exposure (data not shown).

Conclusion. Taken together these results suggest that OTA and AA have different effects on the different immune parameters at the intestinal level, with important implications for the gut health.

Acknowledgements. This work was financed through the project PN-II-RU-TE-2012-3-0086 financed by UEFISCDI.

\section{REFERENCES}

1. Al-Anati L, Essid E, Stenius U, Beuerlein K, Schuh K, Petzinger E. (2010). Differential cell sensitivity between OTA and LPS upon releasing TNF- $\alpha$. Toxins (Basel). 2(6):1279-1299.

2. Mechoud MA, Juarez GE, de Valdez GF, Rodriguez AV (2012). Lactobacillus reuteri CRL 1098 and Lactobacillus acidophilus CRL 1014 differently reduce in vitro immunotoxic effect induced by Ochratoxin A. Food and Chemical Toxicology 50(12):4310-4315.

3. Wu CJ, Chou YC, Cheng YW, Hsiao CJ, Wang $\mathrm{CH}$, Wang HY, Sheu JR, Hsiao G (2011). Aristolochic acid down regulates monocytic matrix metalloproteinase-9 by inhibiting nuclear factor- $\kappa \mathrm{B}$ activation.ChemBiol Interact.192(3):209-219. 